University of Wollongong

Research Online

Faculty of Social Sciences - Papers (Archive) Faculty of Arts, Social Sciences \& Humanities

2011

Population growth and change: implications for Australia's cities and regions

Pauline M. McGuirk

University of Wollongong, pmcguirk@uow.edu.au

Neil Argent

University of New England

Follow this and additional works at: https://ro.uow.edu.au/sspapers

Part of the Education Commons, and the Social and Behavioral Sciences Commons

Research Online is the open access institutional repository for the University of Wollongong. For further information contact the UOW Library: research-pubs@uow.edu.au 


\title{
Population growth and change: implications for Australia's cities and regions
}

\author{
Abstract \\ Australia's distinctive pattern of settlement has long presented a suite of social, economic, infrastructural, \\ and environmental challenges for the nation's cities and regions. These challenges will be intensified by \\ the population growth and dynamics anticipated in the 2010 Intergenerational Report. Future growth will \\ inevitably have differential impacts for metropolitan, regional, and rural settlements, and for inland and \\ coastal regions. This paper analyses current trends and likely directions in population change and \\ distribution and the major implications for the nation's metropolitan and non-metropolitan areas. For \\ Australia's cities, core issues include: access to affordable housing, suitable employment, infrastructure, \\ and services; managing growth within environmental constraints; and the political management of \\ popular anxieties around urban diversity and consolidation. For rural regions, processes of depopulation, \\ demographic decline, ageing, and threats to community socio-economic viability are intermingled with \\ differential patterns of repopulation and consolidation, and issues of growth management. While the \\ paper works through the distinctive character of the issues facing urban and regional contexts, it also \\ highlights the interconnected nature of demographic change in Australia's settlement system and the \\ questions that these pose for urban and regional governance. \\ Keywords \\ growth, population, change, implications, regions, australia, cities \\ Disciplines \\ Education | Social and Behavioral Sciences \\ Publication Details \\ McGuirk, P. \& Argent, N. (2011). Population growth and change: implications for Australia's cities and \\ regions. Geographical Research, 49 (3), 317-335.
}




\title{
Population growth and change: implications for Australia's cities and regions
}

\author{
Pauline $\mathrm{M}^{\underline{c}}$ Guirk
}

Neil Argent

\section{Published in Geographical Research 2011}

\section{ABSTRACT}

Australia's distinctive pattern of settlement has long presented a suite of social, economic, infrastructural and environmental challenges for the nation's cities and regions. These challenges will be intensified by the population growth and dynamics anticipated in the 2010 Intergenerational Report. Future growth will inevitably have differential impacts for metropolitan, regional and rural settlements, and for inland and coastal regions. This paper analyses current trends and likely directions in population change and distribution and the major implications for the nation's metropolitan and non-metropolitan areas. For Australia's cities, core issues include: access to affordable housing, suitable employment, infrastructure and services; managing growth within environmental constraints; and the political management of popular anxieties around urban diversity and consolidation. For rural regions, processes of depopulation, demographic decline, aging and threats to community socio-economic viability are intermingled with differential patterns of repopulation and consolidation, and issues of growth management. While the paper works through 
the distinctive character of the issues facing urban and regional contexts, it also highlights the interconnected nature of demographic change in Australia's settlement system and the questions that these pose for urban and regional governance.

KEYWORDS Population projections, Urban and regional settlement, Metropolitan growth management, Non-metropolitan growth, decline and change

\section{Introduction}

The release of the 2010 Intergenerational Report (IGR) re-ignited the long-simmering national debate over Australia's optimal population size. With some alarm, headlines from the major broadsheet newspapers told of the IGR's long range forecast of 36 million Australians by 2050, together with a world-leading 65 per cent growth rate (Irvine and Saulwick, 2009). The IGR's release coincided with official statistics highlighting that recent very high immigration intakes are driving the nation's rapid growth, with total permanent and long-term arrivals reaching over 660000 in 20082009 (DIAC, 2009). Almost simultaneously, Australian Bureau of Statistics' projections also foreshadowed rapid future growth, overwhelmingly concentrated in the capital cities.

As is somewhat typical of documents such as the IGR - conceived, researched and written from the perspective of the political centre - the true picture of population growth (and decline) at the regional scale, was glossed over. Yet central to a detailed and policy-relevant understanding of many of the IGR's headline concerns is the 
question of population distribution, particularly the very substantial differences in demographic composition and change at sub-national levels across the settlement system. In this paper we analyse the current trends and likely directions in population change and distribution of Australia's cities and non-metropolitan regions. We are particularly concerned to draw out the major implications of these highly differentiated trends and processes for the delivery of key infrastructure and services as well as for socio-spatial equity and the environment.

The paper is structured in three main sections. First we review recent settlement trends and projected patterns of demographic growth and change. Section two surveys the growth management challenges facing the major cities around employment, housing, accessibility, affordability and environmental constraint. It highlights the critical importance of spatially sensitive infrastructure investment to managing these challenges and to allaying popular anxieties around urban growth. Section three addresses the complexities of non-metropolitan settlement trajectories and considers the possible effects on these of regional and other policies. As we highlight throughout the paper, while some settlement zones within the nation face quite starkly contrasting demographic trajectories, we choose to emphasise the essentially inter-related and integrated nature of population processes between the 'command posts' of the national economy - the capital cities - and the nonmetropolitan cities, regions and towns. We conclude by reflecting on the constructed dichotomy of a 'big Australia' and 'a sustainable Australia' and point to the importance of governance in mediating future settlement directions. 


\section{Settlement patterns and projected demographic growth and change}

The dominant characteristics of the Australian population and its settlement pattern are well known: its relatively small size compared to other countries of similar levels of development; its high degree of geographical concentration especially in its largest cities and, concomitantly, the very low population densities prevailing over substantial portions of the continent (Holmes, 1987, p.24). Critically for the focus of this paper, the capital cities' position atop the settlement hierarchy was consolidated by the particular pattern of industrial and economic development inherent to imperial trade. Transport infrastructure, as the skeleton for the settlement system, was laid out so as to best facilitate the efficient drainage of gold, wheat, wool and meat - the four key staples of $19^{\text {th }}$ century economic expansion - from the regions to the capital cities and chief entrepôts.

Recent population projections reflect and underscore the prevailing features of the Australian settlement system, together with the dominant drivers of change. The first point that must be understood is that net overseas migration will be the dominant driver of future population growth notwithstanding the recent increase in the fertility rate. In recent decades, 60 per cent of national population growth has been driven by immigration and this trend is expected to persist (Commonwealth of Australia, 2010). This is a critical point, not least because accounting for medium- to long-term migration flows is a problematic aspect of projection methodology (see Bell and Wilson, this edition). The second major point is that while the precise trajectory of projected population growth varies according to source and set of assumptions, all assessments concur that the bulk of population expansion will be captured by the 
major cities, particularly the capital cities. Immigration flows to Australia over the past decade and a half have increasingly focussed on the major cities, with 89 per cent of post-1996 immigrants making their home there (Hugo, 2008b). While the proportion settling in provincial cities has remained stable, the proportion in the major cities has grown such that, by 2006, 79 per cent of the overseas born lived there while just 7 per cent lived in rural areas (Hugo, 2008a). Notwithstanding the diversion of some migrants from the large cities via DIAC's State Specific and Regional Migration Program, this trend is likely to continue.

\section{INSERT FIGURE 1}

Fig. 1 shows the share of the Australian population living in urban centres of varying sizes and the rural remainder for the 1966, 1996, 2001 and 2006 Censuses while Table 1 displays the growth of each of the major settlement categories in raw numbers.

Overall, the broad pattern of population distribution has altered relatively little between 1966 and 2006, especially when it is considered that the total population grew by nearly two-thirds over the same period. Despite the still popular 'bush' imagery, Australia is an urban and littoral nation and is likely to remain so for the foreseeable future (McDonald 2008). By 2006, 88 per cent of the population lived in urban settlements and 85.3 per cent lived within 50kms of the coast (Hugo, 2008a). Of the total population, 75 per cent $(16.7 \mathrm{~m})$ now live in the major cities (population $>100$ 000) and fully two-thirds live in the capital cities (see Fig. 2). Between 2001 and 2006, 82.6 per cent of population growth was concentrated in the major cities and 66.2 per cent in the capitals (Major Cities Unit, 2010).

INSERT FIGURE 2 
Long established metropolitan primacy is likely to become even more entrenched as the major cities maintain their role as the key population absorbers (Newton, 2008a). All of Australia's largest cities are predicted to undergo substantial growth in the coming decades. Of the predicted national growth by 2056,72 per cent is expected to be captured by the capital cities: an additional 10m people (Major Cities Unit, 2010). This would place Sydney and Melbourne at roughly $7 \mathrm{~m}$, with 56 per cent and 71 per cent increases respectively on 2010 estimates (ABS 2008). Perth is predicted to reach just over 3.3m, growing by 104 per cent, while Brisbane will reach almost 4m growing by 103 per cent. Darwin will grow by 94 per cent to reach 240000 and the ACT by 46 per cent to reach 506000 . Adelaide and Hobart are predicted to grow more slowly with Adelaide growing by 39 per cent to reach $1.6 \mathrm{~m}$ and Hobart growing by 32 per cent to reach 278000 (see Fig. 3).

\section{INSERT FIGURE 3}

Yet this ostensibly inexorable trend towards intensifying urbanisation obscures a dynamic settlement system likely to undergo new transitions as it encounters a changing interplay of socio-demographic and economic factors with intensifying environmental constraints. Recent settlement dynamics include the emergence of peri-urban zones of mixed urban and rural land uses, reaching $100 \mathrm{~km}$ from the major cities' centres and made possible by improved transport and communication infrastructure and growing preference for semi-rural situations (Bell, 1996; Newton, 2008b). Settlements just beyond the commuting zones of the major metropolitan centres have also expanded. But a more prominent phenomenon has been the emergence of growth centres along the high-amenity eastern, south-eastern and 
south-western coastal zones as substantial flows of both retirees and young families reshaped these areas as sea-change settlements (Essex and Brown, 1987; Burnley and Murphy 2004). The official population projections of the various State Governments generally covering the period 2006 to 2031 - reveal that peri-metropolitan and highly accessible coastal regions will likely experience the fastest rates of growth outside of the capitals. In some cases, annual average rates of growth are projected to exceed those of the metropoles, although this growth is from a small base (e.g. Mackay and Wide Bay-Burnett SDs vis-a-vis Brisbane in Queensland). These combined patterns are already consolidating the emergence of extensive metropolitan regions, formed by the large cities' outward growth, peri-urban developments and enhanced links with their surrounding second tier cities. Four such mega-metro regions are in formation and have been adding population at well above the national average (Newton 2008b): Newcastle-Sydney-Wollongong, Geelong-Melbourne-Mornington Peninsula, Wanneroo-Perth-Mandurah, and Sunshine Coast-Brisbane-Gold Coast.

On the other hand, less buoyant trajectories are projected for the majority of nonmetropolitan regions, substantially due to their relative inability to attract a more sizeable share of the national immigration intake'. Similarly, inland regions with reasonable accessibility and some capacity for attracting tourist and amenity migrant flows are expected to see at least gentle growth over the medium term. For the remoter, drier inland regions, though, long-term stability or slow decline is the best the projections can offer (South Australian Department of Planning and Local Government, 2010; Queensland Government, 2008; Department of Planning, 2008). Naturally, though, aggregate trends at such a broad scale of analysis disguise a considerable degree of local variation around the mean. 
Of course, the composition of demographic change will potentially impact on Australia's settlements as profoundly as the actual dimensions of growth and/or decline itself. Most notable here is the ongoing 'greying' of the population. The IGR predicts that $8.1 \mathrm{~m}$ of the population ( 23 per cent) will be 65 and over by 2050, up from 2.6m (13 per cent) in 2006 (Commonwealth of Australia, 2010). The next two decades will bring the exit of the 'baby boom' cohort from the workforce, with significant settlement implications. This relatively large and wealthy cohort is predicted to be highly mobile, suggesting they will contribute to the sea change, empty-nest and 'grey nomad' phenomena (Bell and Ward, 2000)). And the strong tendency for the population of the larger cities to be younger, capturing flows of youthful international and internal migration, points to challenging times for inland towns and nonmetropolitan areas. Hence, the seemingly ubiquitous experience of population ageing will have its own quite diverse geography (see Fig. 4). Notwithstanding the insights contained within these various projections, it is important to apprehend the complex ways in which migration and natural increase/decrease interact with each other to drive demographic change at regional and local scales - the very levels at which decisions concerning key infrastructure and service provision need to be made. We return to this theme in the following sections.

INSERT FIGURE 4

\section{The major cities: managing growth}

As a nation of cities, the functioning of the major cities is critical to Australia's potential to achieve ongoing productivity, liveability and sustainability. Substantial urban growth, and more particularly the assured substantial growth of the largest 
metropolitan regions, has profound implications. While projected growth rates are no greater than in the 1960s and 1970s, the context has profoundly shifted to one of global economic uncertainty, climate change, and intense resources constraints. Urban population-led development presents a formidable set of interlocking socio-political, economic and environmental challenges-some key dimensions of which we work through below. Yet increasing city size and intensified urbanisation are not inherently problematic. Indeed, cities are increasingly seen as the most likely source of innovations and solutions to the global crisis of sustainability (Davis 2010, Newton and Bai 2008). Nonetheless, sustainably managing cities' growing size and complexity-the face of Australia's metropolitanised future-suggests the need for fundamental transformations including in urban spatial structure and, crucially, in urban infrastructure as one of the key means of supporting and directing growth. Achieving this presents an overarching challenge to the current governance model. We return to this in the paper's conclusion.

Employment, housing, accessibility, affordability

Projected population growth and change will heighten the challenges of maintaining urban economic productivity; enhancing accessibility across cities' increasingly spatially-complex labour markets; and securing equitable access to housing, social infrastructure and services. Apart from being the major population absorbers the major cities, specifically the capitals and their surrounding urban regions, are undeniably the drivers of the national economy and productivity. They currently generate 80 per cent of GDP, employ 75 per cent of the workforce and contributed 81 per cent of national net job creation 2001-2006 (BITRE, 2009). But substantive 
additional job generation will be needed to support population growth. Current capital city metropolitan strategies suggest the need for an additional 760000 jobs in Sydney, 353000 in Perth, and 282000 in Adelaide over the next 30 years or so ${ }^{\mathrm{ii}}$. The regional cities, in their turn, will face similar pressures. Yet the productivity of Australia's major cities has been declining due in large part to infrastructural back-logs. Deficits in economic insfrastructure especially are leading to rising congestion costs.

Infrastructure Australia-the Commonwealth body tasked with producing a strategic blueprint for national infrastructure needs - priced this backlog at $\$ 300 \mathrm{~b}$ or $\$ 13287$ for every Australian (O'Sullian and Wen, 2011). Without infrastructural investment, population growth will see this increase to $\$ 750$ b (Tanner, 2010). BITRE's (2007) calculations pinpoint how these backlogs particularly effect the larger cities. Table 2 summarises BITRE's estimates of the rising social costs of urban congestion for the capital cities.

\section{INSERT TABLE 2}

Population aging and a shrinking workforce represents a further threat to urban productivity (see Fig. 4) . As the IGR argues, population growth and increased labour force participation may be vital to sustaining productivity in face of this inevitable population greying. Yet, in the absence of substantial infrastructural and service investments, urban growth will unavoidably compound the pressures on cities' already congested infrastructural and service capacities, their ability to generate new employment growth and productivity and, crucially, their ability to generate equitable employment opportunity across the urban fabric. Infrastructure and services will be similarly instrumental to addressing the geographical and social complexities of 
Australia's urban employment and labour markets; currently characterised by intense dispersal, differentiation and segmentation. These complexities are likely to increase with population growth and further metropolitanisation. The dislocation of housing and evolving labour sub-markets and the car-only accessibility of many suburban areas have resulted in the marginalisation of some localities from job opportunities and produced rising stresses and inefficiencies and spatial structural imbalances (Gleeson et al, 2010; Baum et al, 2005) ) $^{\mathrm{iii}}$. Currently over $3.3 \mathrm{~m}$ people (25 per cent of Australia's metropolitan population) live in 24 fast growing LGAs on the fringes of the major cities. This is tipped to grow to $4.5 \mathrm{~m}$ by 2021 (Australian Government 2010). With rapid urban population growth, including on the urban fringe, the question of job accessibility across geographically and socially complex urban labour markets will be fundamental. For the regional cities, these issues take on an additional dimension. Their economies can be characterised as predominantly consumer service economies. Future growth in an increasingly higher-order service and hi-tech oriented economy is likely to be 'smart growth' dependent on human capital which is currently heavily concentrated in the top five cities $^{\text {iv }}$. An additional challenge for regional cities will be to capture higher quality economic growth, generate a greater job mix and develop the education and skills base of the workforce. For those cities within the orbits of emerging metropolitan regions (Newcastle, Wollongong, Geelong, Gold Coast, Sunshine Coast), building the connectivity and functional interdependency with the larger cities must be prioritised.

But, problematically, current infrastructural deficits inhibit access to employment opportunities for many residents because of poor local availability of transport and, crucially, social infrastructure: that is, the education and training, childcare, health and 
community services that also determine people's ability to access employment opportunities (Fagan and Dowling, 2005). Historic shifts away from debt-financed public provision of such infrastructure and services on a universal basis, and the uneven spatial patterning of private sector provision, has intensified socio-spatial disparities across urban communities across all Australia's metropolitan centres (O’Neill, 2010). Securing equitable access to a diversity of job opportunities, transport, social infrastructure and services will be one of the fundamental growth management issues for a 'big urban Australia', crucial to urban economic and social well-being, to urban economies' ability to deal with exogenous pressures, and to the broader issues of urban socio-spatial equity and environmental sustainability.

Beyond questions of employment distribution and diversity, accommodating major urban population growth will induce substantive increases in housing demand, exacerbated by the shrinking household size associated with socio-demographic trends: notably aging and the related rise of lone-person households. Nationally, the number of households is expected to increase from $7.8 \mathrm{~m}$ to $11.8 \mathrm{~m}, 2006-2031$, adding $4 \mathrm{~m}$ additional households in 25 years. Population aging will bring substantial transformation to household composition too. Couples without children will become the dominant family type by 2014. And, showing the most rapid growth of all household types, the number of lone person households will increase from 1.9m (24 per cent) to $3.6 \mathrm{~m}$ (30 per cent) by 2031 (ABS 2010). The impact of these changes on housing demand will intensify the need for effective combinations of targeted fiscal incentives, planning mechanisms and infrastructural investments to address housing access, diversifying demand and urban affordability. Australia's current urban housing context is already pressured. Table 3indicates the scope of housing demand projected 
in current metropolitan strategies. The National Housing Supply Council (2010) identifies a current shortfall of 178000 dwellings and, under medium growth projections, anticipates a national cumulative gap of 640600 dwellings by 2029 . This gap is at its most concentrated in cities where demand is highest and where high land and construction costs have acted as disincentives to the private development of affordable housing. Surging demand coupled with housing supply shortages has also led to escalated housing costs: since the 1980s, the average capital city house price increased from the equivalent of 3 years to 7 years average earnings (Senate 2008) ${ }^{v}$. Housing in accessible locations has been pushed well beyond the affordable reach (ie within 30 per cent of income) of low to moderate income people who have sought housing in less well-served outer suburbs, facing long commutes to access work opportunities, services and amenities and being highly vulnerable to fuel and transport cost hikes (Dodson and Sipe, 2008).

\section{INSERT TABLE 3}

Recognising this, all the long-term capital city metropolitan plans aim to address housing supply and affordability through improved land release programs, affordable housing requirements or planning agreements, and measures to encourage housing diversity to match the household diversity associated with socio-demographic change. However, there is some tension between these housing aspirations and the environment-oriented urban containment strategies also embedded in every metropolitan plan which limit new land release and focus on 'compact city' infill and densification. Containment combined with population growth can push up prices locally through scarcity especially when not adequately matched by increased dwelling 
density in affordable locations and, particularly, when the institutional means to support the supply of affordable housing are still lacking in terms of governance structures $^{\text {vi }}$, local development incentives and macro-level fiscal and housing investment strategies (see Gurran, 2008; Forster, 2006). Again, infrastructure and service planning and investment will be critical to resolving this tension. Enhancing their amenity and locational advantages of both new release and in-fill areas through infrastructural provision can achieve multiple outcomes. It can increase the market supply of housing across the spectrum by making residential investment attractive to developers. It can support increased development densities and leverage affordable housing provision from the higher development values generated by increased densities (see Gurran, 2008). Of course it may also address the locational disadvantages experienced by lower to moderate income households who have sought affordable housing on the urban fringes. As Australia's urban population grows, managing the housing question will be one of the most complex challenges to be tackled, yet it is central to ensuring that the structural and intergenerational inequities induced by uneven access to housing, homeownership and related wealth accumulation do not become more entrenched. ${ }^{\text {vii }}$

In addressing the interlocking challenges of employment, housing, accessibility and affordability in a 'big urban Australia', the infrastructure challenge will be a defining one. Although current political discussion focuses strongly on economic infrastructure, strategic investment in economic and social infrastructure and services will be one of the most effective levers in directing urban growth and development within the metropolitan areas and across the regional cities. In this regard, Federal and state governments' recent turn to prioritising integrated infrastructure planning, investment 
and financing is long overdue. As the cities grow, how successfully the effective, equitable and spatially-sensitive provision of urban infrastructure and services is handled will, to no small extent, define Australia's future economic prosperity, sociospatial equity and wellbeing, and broader resilience and sustainability.

\section{Resources and environment}

Environmental and resource constraint is interwoven into all other aspects of urban population growth. The spatial structure of Australia's cities was shaped in an era of cheap fuel and energy, relatively plentiful water and cheap land. High consumption and high emissions lifestyles are embedded in their functionally separated land uses, housing mix and transit systems. They are consuming environmental resources at a manifestly unsustainable level and consumption rates continue to grow faster than population growth (Newton and Bai, 2008). They are world leaders in terms of per capita water use, energy use, waste generation, carbon emissions, dwelling size ${ }^{\text {viii }}$, mobility by car and, unsurprisingly, environmental footprint (Newton, 2008b). Sharpening resources constraints, particularly around energy, water and land, will shape their futures as oil reserves and rainfall decline and further outward expansion threatens local food production capacity on the peri-urban fringe (Houston, 2005) ${ }^{\text {ix }}$. Yet many agree 'the challenge of achieving sustainable development in the 21st century will be won or lost in urban Australia' (Newton, 2008a, 131), through the development of sustainable urbanism within the limits of resource constraints. Achieving sustainable urbanism while accommodating future growth will demand substantive change and require a combination of transformative technologies (eg integrated urban water management systems, decentralised decarbonised energy 
systems, fast-rail systems etc) which might enable new development trajectories; change in urban development form and spatial structure (land use arrangements, density, design etc) which might rework social, economic and spatial relations and dramatically reduce energy needs and emissions; and change in values and behaviours which might reduce absolute consumption intensities (see Newton, 2008b). In the limited space available here, we chose to focus on the implications of urban population growth for urban water, highlighting both the challenges of growing urban resource demands and the potential for meeting them through technological, structural and behavioural change.

Urban population growth pushes hard up against water resource constraints not least because all Australia's major cities are located in areas of climate change-induced rainfall declines, with further reductions of uncertain magnitude predicted in coming decades (Kaspura, 2006). Current centralised and aging systems for urban water delivery demand substantial redesign, reconceptualisation and reinvestment even without projected population growth (Troy, 2001). Water restrictions and voluntary conservation measures adopted during recent drought conditions have, substantially, already yielded their reductions in consumption rates (Kaspura, 2006). Cities' growth, then, will inevitably bring increased demand which, without significant technological, morphological and behavioural adaptation, will not be sustainable.

\section{INSERT TABLE 4}

New and infill urban development can incorporate higher densities which can reduce water consumption, optimistically by 30-50 per cent (Moriarity, 2002), water efficient appliances, and water sensitive design can simultaneously reduce demand and enable 
rainwater catchment such that, as Table 4 indicates, per capita consumption in the capital cities is expected to remain stable or marginally decline. Nonetheless, using medium population projections, major urban centres' demand for water is projected to increase by 42 per cent by 2026 , or 631 b litres annually, and by 76 per cent or 1147b litres annually by 2056 (WSSA, 2010) ${ }^{\mathrm{x}}$. And, accounting for climate changeinduced rainfall reduction, Berger (2010) suggests that to manage increased urban population, significant reductions in per capita usage will be needed: for example Melbourne's consumption per capita per day would need to be reduced to $c 801$. Whether at stable or significantly reduced consumption rates, coping with aggregate new population-growth-induced demand will bring substantially greater environmental pressures on urban water supply.

Securing resilient urban water supply at higher population levels, regardless of likely additional climate change impacts, will inevitably require a dramatic shift away from the historical paradigm of a highly centralised one-pass system ${ }^{\mathrm{xi}}$ towards decentralised systems and a wider range of water supply sources. Storm water use and domestic harvesting which convert 'wastewater' to water resource have met less resistance than energy-intensive, costly desalination: yet currently all the capital cities have desalination plants in operation or nearing completion. Water recycling has commenced for non-potable uses, increasing in the capital cities by 52 per cent between 2005/6 and 2008/9 (WSSA, 2010) ${ }^{\mathrm{xi}}$. Public perception is likely to be a significant impediment to wider adoption of recycling for potable uses; as evident in Toowoomba's overwhelming rejection in 2006 of a plan to augment city's water with treated effluent. The potential to establish water markets to enable rural to urban trading (WSSA 2010) is likely to be similarly contentious. Securing water for enlarged 
major cities' populations, such that resource and environmental sustainability is within reach, will involve the political negotiation of contested environmental values, perceptions and behaviours, along with substantial infrastructural transformations, planning and investment.

\section{Popular angst and urban population growth}

The political negotiation of environmental values brings us to the wider question of the political tensions surrounding urban population expansion. Population growth has generally proven to be a divisive and politically sensitive issue: the recent Australian Survey of Social Attitudes indicated that 72 per cent disagree with the statement 'Australia needs more people' (Betts, 2010). And Federal Government's response to this sensitivity includes shifting its stance on demographic growth from a 'big Australia' to the more benign 'sustainable Australia'. At the urban scale, the prospect of growth induces popular angst that finds at least two forms of expression: tensions around further migration and urban multiculturalism, and rejection of policies aimed at urban consolidation. Arguably, both can be connected to the critical question of infrastructure and service provision as fundamental to popular acceptance of the implications of population expansion.

Current and future capital city growth is closely interlinked with international migration. Sydney and Melbourne's recent growth has depended on international migration over natural increase or interstate migration and it has been a major constituent of growth in Perth, though less so for Brisbane and Adelaide (McDonald, 2008). The major cities therefore dominate as 'EthniCities' (Forrest and Dunn, 2007) ) $^{\mathrm{xiii}}$. Notably, 93 per cent of migrants from non-English-speaking backgrounds live there 
(IGR, 2010). Given strong labour demand and the trajectory of population aging, current levels of immigration are likely to be maintained: and likewise the geographical concentration of settlement. The fact of language, religious and cultural diversity will therefore continue to shape the major cities' landscapes and their social and cultural geographies. Yet, within a wider context of generally harmonious living, the prospect of further population growth and related diversity has triggered some popular anxiety around geographical concentrations of migrants-particularly of visible minoritieslinked to complex concerns about social cohesion, diversity and cultural identity (Wise, 2010). The major cities have been the flashpoints from time to time for troubling, sometimes violent expressions of these anxieties ${ }^{\text {xiv }}$. Critically, though, there is some evidence that the basis of these concerns are shifting from a complex of fears around cultural difference and its impacts, to disquiet about further pressures on already straining social and economic infrastructure (Narushima, 2010).

These concerns are echoed in the resistance that has met planning prescriptions, embedded in all capital cities' metropolitan strategies, for consolidation and increased densification to accommodate growth whilst constraining resource use and emissions. Transforming existing urban structure and morphology will inevitably meet impediments, given the unavoidable disruptions involved and the challenges posed to deeply rooted cultural preferences for suburban densities (see Newton, 2008b, Davidson, 2006). Densification has been challenged on the basis of impacts on liveability, affordability and equity, and the loss of biodiversity, water catchment and food production capabilities (Newton, 2008b). Yet popular anxieties have solidified more so around the anticipation of stressed services, congested infrastructure, loss of urban character, loss of open space, environmental amenity and liveability (ACD, 2010, 
Gleeson et al, 2010, Kelly, 2010). Highly polarised debate has heightened the defensive localism that has seen governments-federal through to local-backing off the challenge of consolidating most established suburbs, to focus 'compact city' planning on selected growth nodes and increased densities in greenfield developments (see Buxton and Scheurer 2007, CLLM 2010).

Legitimate public anxieties are only likely to be assuaged by substantial and up-front investment in the physical and social infrastructure and services necessary to support densification, provide public collective amenity as a trade-off for the private amenity characteristic of low density suburban form, and absorb increased usage and growing demand. But the lack of integration of higher density development with public transport and social infrastructural improvements and new investments thus far has contributed to poor public confidence (Gleeson et al, 2010). This has also fed public discomfort and doubt about cities' capacity to absorb substantial additional growth without exacerbating service shortfalls, locational disadvantages, and the potential for intensified socio-ethnic fragmentation. However we, as a political constituency, are prepared to fund it, it is clear that substantive and carefully planned investment in infrastructure and service delivery, integrated with spatial planning will shape the success (or otherwise) of urban population growth management on multiple fronts including: 1. providing the basic foundation to support social cohesion across a culturally diverse population; 2 . galvanising transitions to more compact urban forms to absorb growth with lower environmental costs; and 3. allaying complex public anxieties about the impacts of a 'big urban Australia'. 


\section{Non-metropolitan regions: managing growth, decline and change}

While the challenges facing the major cities concern managing growth, those facing the non-metropolitan regions are more complex. Some stereotypes of nonmetropolitan areas conform to the notion of an urban-rural continuum where community socio-cultural, demographic and economic diversity and dynamism is negatively related to remoteness. For Hugo $(2005,78)$ :

... there is a widening polarisation occurring in non-metropolitan Australia. The rangelands are generally experiencing depopulation, dominated by school leavers; however, there are substantial areas in the better-watered and more accessible parts of non-metropolitan Australia that are continuing to experience significant and sustained net-migration and population growth.

At finer scales of resolution, though, a more complex picture emerges. Consistent with the notion of the 'multifunctional countryside' (see Holmes, 2006; Argent, 2002), Smailes, et al. (2005) have explored the differing demographic character of the major regional types found within the Australian ecumene (illustrated for south-eastern Australia in Fig. 5), together with the various trends and processes driving change within them over the past two and a half decades (see Table 5 ).

Table 5 shows the relative status and change in three defining qualities of rural settlement in Australia: community central town population; the proportion of the community population living in urban centres; and the density of the community population living outside of towns. Taken together, these indicators capture the relative attractiveness of a community (i.e. a central town and its hinterlands) to established and prospective new residents in terms of the level of public and private 
services likely to be available, possible employment opportunities, together with the likely intensity of sporting and social interaction. Individually, of course, they refer more specifically to important features of rural life (Smailes, et al. 2005). Using median values for the central town of the community, the table shows robust growth (c. 2 per cent per annum) for the main towns of the coastal and mixed farm belts, and more subdued but still healthy growth in the high access zones that fall between them. In the most sparsely settled inland and remote zones where town sizes are also, on average, the smallest, the aggregate trend of stability over the twenty year period masks some very substantial population loss. As already observed in Fig. 1, the urbanisation of the rural population has also increased since 1981, with the coastal zone seeing the fastest increases, together with the highest overall proportion of the community population living in towns. In striking contrast to the discourse of decline that has enveloped much of the discussion of Australian rural towns over the past decade, the fastest rates of growth by settlement category have been recorded for the smallest centres, particularly in the most accessible and densely settled zones ('high access', 'mixed farm' and 'coastal'). Finally, rural population densities (excluding the townships) are highest, and have seen the most rapid increases, in the coastal and high accessibility zones, while net densities have declined in the more agriculturallydependent inland and remote zones (see Figs. 5 and 6). Therefore, as a qualification to the trend towards increased urbanisation, rural populations have continued to grow in the so-called 'tree change' and 'sea change' zones. However, growth has been the exception rather than the rule in agricultural heartland regions.

Clearly, migration processes will continue to play a dominant role in shaping these trends. A recent analysis of migration trends and processes for inland Australia from 
1976 to 2001 revealed that, while rates of out-migration and net migration loss fluctuated throughout the period, for most inland, agriculturally-dependent regions this was a time of unremitting substantial outflows (Walmsley, et al. forthcoming). Crucially, the youth and working aged comprised the major - and a growing - share of these outflows (Tonts, 2005). Australia has a high level of youth migration: 52 per cent of all people aged 15-24 years changed residence in the five years to 2001 (ABS 2003) and age-specific migration rates for rural 15-24 year olds are among the highest of any age group nationally (Walmsley et al., forthcoming). Moreover, migration rates for this age group have increased over time. Spatially, youth out-migration encompasses virtually all non-metropolitan regional types, even the popular rural coastal strip that has been the major beneficiary of counterurbanisation inflows has experienced substantial outward movement by local youth. Further, and contrary to the popular conception that young rural people overwhelmingly flock to the 'bright lights' of the cities, Argent and Walmsley (2008) revealed that many young people leaving the Western Australian central wheatbelt and the New South Wales Northern Tablelands during the 1990 s relocated elsewhere within their respective 'home' region. Nonetheless, the heaviest youth net migration losses have been associated with the more isolated, agriculturally dependent communities. Cumulatively, these outflows of the so-called 'nubile cohorts' undermine the capacity of the community to replace itself, leading to long-term social, demographic and economic decline (see Tonts and Atherley, 2005).

For every migration current there is a counter-current, and many declining small, inland regions exhibit comparatively high in-migration rates (Tonts, 2005; Argent, et al, 2010). Thus, it is important to pay careful attention to net migration and migration 
effectiveness to appreciate the complexities of population growth and decline in rural Australia, and its potential future trajectories. Over the past three decades, counterurbanisation flows have delivered substantial numbers of ex-urban migrants to rural regions, though the size of these flows has gradually dwindled and become much more spatially selective in terms of destination regions and localities (Hugo, 2005). It is important to realise, in the context of this discussion of the ongoing and likely future rapid growth of the capitals, that Sydney loses many more people to the rest of New South Wales, and to the rest of the nation, than it receives in return (Bell and Hugo, 2000). These ex-urban migrants have primarily bolstered the populations of mostly nearby regions (i.e. the Hunter Valley and Illawarra) but also contributed significantly to migration flows to the coastal belt and high amenity inland regions (Argent, et al., 2007; Argent, et al. 2011). The populations of major regional centres have also been augmented by ex-urban migrants, with in-migrants from the hinterlands generally comprising smaller shares, in spite of their popular characterisation as 'sponge cities' (Alexander and Mercer, 2007; Argent, et al., 2008). The interconnectivity of settlement and demographic shifts is further reinforced by the increasing complexity of well-established patterns whereby people live in one type of settlement and work in another. Improved mobility has seen an increase in a wide range of temporary migration streams, including 'fly-in, fly-out' arrangements, multiple home ownership, winter movements from north to south, seasonal 'harvest trails' and the like, all of which underline the growing volatility of settlement patterns (Bell and Ward, 2000; Hugo 2008a).

For some regions, particularly those in the coastal and other high amenity zones, the growth of the capitals offers up the potential opportunity to attract in more ex-urban 
migrants and consolidate or expand their economies. Australia has a long if not very distinguished history of government-led attempts at population and industry decentralisation (Beer, 2000), including the Whitlam Government's 'New Cities' programme. This programme was strongly influenced by notions of ideal city size, based on social, economic and public health criteria (Neutze, 1978; Self, 1995). Despite the putative failure of this and related initiatives, demands for a strategically coordinated approach to population and business decentralisation have not disappeared. However, with neoliberalism's strengthened ideological grip of regional policy from the 1980s (Beer, 2000; Tonts and Haslam-McKenzie, 2005) governments have been reluctant to play more than a facilitative role in such initiatives, preferring to let community groups and the private sector take the lead. Numerous rural communities now mount festivals celebrating a bewildering range of cultural and natural attractions in order to attract elusive tourist and migrant flows (e.g. Brennan-Horley, et al., 2007), with or without government funding. In addition, initiatives such as CountryWeek (now known as the Country and Regional Living Expo) have directly marketed the positive attributes of rural communities to Sydney and Brisbane residents through a regular annual showcase held in each city. This is now being complemented by the joint Federal/NSW State Government-funded 'EVOcities' programme which is aimed at attracting Sydney residents disenchanted with the many diseconomies of metropolitan life to relocate to the seven major regional centres of inland New South Wales: Albury, Wagga Wagga, Bathurst, Orange, Dubbo, Tamworth and Armidale. A key to the success, or otherwise, of such programmes, is the ability of these regional centres and the nearby smaller towns that will also likely benefit from any local spread effects - to provide key services and infrastructure to meet demands. The roll-out of fast and 
reliable broadband is likely to be crucial here, offering a potentially wide range of business, educational and health service opportunities to rural communities, large and small.

Over recent decades, the massively destructive effect of public efforts to foster inland settlement via 'closer settlement' policy has been realised. For many inland regions, one area of uncertainty that casts a shadow over their potential population growth (and decline) is the increasing prominence of agri-environmental regulation in the face of tightening environmental constraints. One issue looms above all others for the eastern and southern states: the imposition of 'sustainable diversion limits' (SDLs) on outtakes from within the Murray-Darling Basin rivers (MDBA, 2010). At this early stage, the full implications of the Basin Plan for settlements are unclear - not least because the protracted consultation and implementation process has only just begun. It seems certain, though, that Australia's food bowls will be forced to depend much less on irrigation. Given the already massive disruptions that the many towns and regions of the Basin have already experienced at the hands of two decades of agricultural restructuring and the downstream processing of food and fibre commodities - all of which have fuelled out-migration flows - just what impact the likely introduction of permanent cuts to river diversions will have on inland population trends is unclear. Given the focus of this special edition, it is perhaps more appropriate to consider the adaptive capacities of Australian food producers to adjust to a drier and altogether more uncertain future and to continue to provide sustenance to a rapidly growing population, whatever its distribution (see Foran and Poldy, 2003). 


\section{Conclusion}

"If you're not in Sydney, you're camping out" Paul Keating (1993).

“A bigger Australia doesn't mean deeper soils, it doesn't mean larger river flows, it doesn't mean more rainfall. We're only bigger in one sense - the increase in the total number of humans crammed into the narrow coastal strip" Bob Carr (2010).

Since 1788, the contested relationships between population and environment have been central to the discussion of what sort of society Australia should be (see Hugo, this edition). The two quotes above underscore how the debate over Australia's optimum population can subtly yet substantially polarise traditionally staunch allies. Former Prime Minister Keating and former NSW State Labor Premier, both intellectual leaders of the Labor Right, hold strongly contrasting views on the implications of the likely rapid future growth of the national population and, particularly, for the nation's capital cities. In many respects, they encapsulate the major concerns about future population growth and its distribution. On the one hand, there is the cold, hard demographic reality, displayed in a range of official projections, of substantial population growth over the next few decades, with the majority of this within the nation's metropoles and their burgeoning conurbations. For some, including Keating, this outcome is merely a reflection of the capitals' largely unrivalled position as the centres of economic and political might and the incubators of innovation. As we have attempted to stress in this paper, the projected levels of growth - although by no means unprecedented - will not be easily accommodated within the existing infrastructure, nor within the same energy-intensive paradigm of production, 
consumption and distribution, and certainly not within the same disjointed approach to urban planning, policy and governance.

Governance systems will be fundamental to achieving the transitions necessary to address new growth pressures. Managing growth demands a reconceptualisation of urban governance and its ambition, posing a paradigmatic challenge to institutions and practices of the current model ${ }^{\mathrm{xv}}$. Multi-level governance fragmentation and complexity is compounded by inconsistent integration across development, infrastructure and human services planning, and between strategic planning and implementation, and by the absence of effective metropolitan-level implementation capacity (Spiller 2010). Accommodating growth and mobilising the longterm restructuring of problematic landuse and transport patterns and functional interactions that characterise Australian cities will require that this governance deficit is addressed (Gleeson et al 2010). Several positive moves are currently underway: The Council of Australian Governments' (COAG) establishment of the Cities Planning Taskforce to drive integrated planning and multi-level coordination and to link federal urban and infrastructure funding to national criteria for effective capital city planning are positive moves ${ }^{\mathrm{xvi}}$, as is the production of a National Urban Policy by the Federal Government's Major Cities Unit. Though debate runs hot (e.g Gleeson et al 2010, ADC 2010, CCCLM 2009), for the timebeing, the establishment of metropolitan-level authorities with powers to plan, finance and implement metro-scaled strategic planning and infrastructural investment remains politically sensitive and has not materialised. The prospect of rapid urban population growth has as least galvanised historic efforts to address Australia's urban governance deficits. 
Bob Carr's comments portray a greater sense of caution and a growing concern about absolute growth and its potential to exceed an ecologically-sustainable carrying capacity. The capacity to feed a growing nation, and a sizeable share of the global population, is also coming under question. There is increasing unease that the nation's food bowls, hard hit by a complex of, inter alia, climatic uncertainty, labour shortages, the long-run cost-price squeeze and reduced access to irrigation water, may be unable to meet these growing demands. How the country's food and fibre producers and processors respond to these challenges, and tightening agri-environmental regulation, will therefore be crucial.

Addressing the cascading challenges of population growth demands a detailed understanding of: 1 . the interrelationships and interactions between the various components of the settlement system; and 2. the drivers of change within this system. This paper, for example, has highlighted that beyond the apparent inevitability of the ongoing urbanisation of the Australian population a number of important and, in some zones quite divergent, trends and processes are in play. The deepening flows of people, goods and information between the capitals and the second tier cities and the major inland and coastal regional centres highlight that the conventional rural-urban dichotomy will be less able to capture the complexity and dynamism of Australia's settlement system. 


\section{REFERENCES}

Alexander, S. and Mercer, D., 2007: Internal migration in Victoria, Australia - Testing the 'Sponge City' model. Urban Policy and Research 25, 229-256.

Argent, N., 2002: From Pillar to Post? In Search of the Post-Productivist Countryside in Australia. Australian Geographer, 33, 97-114.

Argent, N., Rolley, F. and Walmsley, D. 2008: The sponge city hypothesis: Does it hold water? Australian Geographer 39, 109-129.

Argent, N. and Walmsley, D., 2008: Rural youth migration trends in Australia: An overview of recent trends and two inland case studies, Geographical Research 46, 139152.

Argent, N., M. Tonts, R. Jones and Holmes, J., 2011: Amenity-led migration in rural Australia: A new driver of local demographic and environmental change? In Luck,G., Black, R. and Race, D. (eds.) Demographic change in rural landscapes: What does it mean for society and the environment? Springer, Dordrecht, 23-44..

Argent, N., Smailes, P., Griffin, T., 2007: The amenity complex: towards a framework for analysing and predicting the emergence of a multifunctional countryside in Australia. Geographical Research 45, 217-232.

Australian Bureau of Statistics, 2003: Population distribution: youth migration within Australia. Cat. No. 4102.0, ABS, Canberra.

Australian Bureau of Statistics, 2007: Households, Wealth and Wealth Distribution, Australia 2005-06. Cat. No. 6554.0, Canberra. 
Australian Bureau of Statistics, 2008: Population Projections, Australia, 2006 to 2101.

Cat. No. 3222.0, Canberra.

Australian Bureau of Statistics, 2010: Australian Demographic Statistics, March 2010.

Cat. No. 3101.0, Canberra.

Australian Bureau of Statistics, 20010: Household and Family Projections, Australia

2006-2031., Cat. No. 3236.0, Canberra.Australian Davos Connection, 2010: Cities

Report: Enhancing Livability. ADC. Available at http://www.adcforum.org/.

Downloaded November $26^{\text {th }} 2010$.

Australian Government, 2010: A Sustainable Population for Australia, Department of Sustainability, Environment, Water, Population and Communities, Canberra.

Baum, S. and O'Connor, K., 2005: Regional population and employment change in Australia 1991-2001: inertia in the face of rapid change? Geojournal 62, 85-94.

Baum, S., Haynes, M., Van Gellecum, Y., and Han, H., 2005: Typologies of advantage and disadvantage: socio-economic outcomes in Australian cities. Geographical Research 42, 361-378

Beer, A., 2000: Regional Policy and Development in Australia: Running Out of Solutions? In Pritchard, W. and McManus, P. (eds) Land of Discontent: The Dynamics of Change in Rural and Regional Australia. UNSW Press, Sydney, 169-194.

Beer, A. and Keane, R., 2000: Population decline and service provision in regional Australia: a South Australian case study People and Place, 2, 69-76.

Bell, M., 1996: Understanding Internal Migration. Bureau of Immigration, Multicultural and Population Research Monograph, AGPS, Canberra. 
Bell, M., and Hugo, G., 2000: Internal migration in Australia 1991-1996, Overview and the Overseas-Born. AGPS, Canberra.

Bell, M. and Ward, G., 2000: Comparing temporary mobility with permanent migration, Tourism Studies 2, 87-107.

Berger, C., 2010: Population: The Big Issue - The National Interest. ABC Radio, Broadcast 21 May 2010.

Betts, K., 2010, A bigger Australia: Opinions for and against, People and Place June. Available at http://findarticles.com/p/articles/mi hb4932/is 2 18/ai n55040856/?tag=content;co 11. Downloaded November 25, 2010.

Brennan-Horley, C., Connell, J., and Gibson, C., 2007: The Parkes Elvis Revival Festival: Economic Development and Contested Place Identities in Rural Australia, Geographical Research 45, 71-84.

Bureau of Infrastructure, Transport and Regional Economics, 2009: Change in Australia's Industry Structure: Main Cities 2001-2006. Information Sheet 32, Canberra. Bureau of Transport and Regional Economics, 2007: Estimating Urban Traffic and Congestion Cost Trends for Australian Cities, Working Paper 71, Canberra.

Burnley, I. and Murphy, P., (eds.), 2004: Sea Change: Movement from Metropolitan to Arcadian Australia. University of New South Wales Press, Sydney.

Buxton, M. and Scheurer, J. 2007: Density and outer urban development in Melbourne. Urban Policy and Research 25, 91-111. 
Carr, B., 2010: 7.30 Report, ABC, $28^{\text {th }}$ June 2010, Transcript available at

http://www.abc.net.au/7.30/content/2010/s2939288.htm. Viewed Dec 2, 2010.

Commonwealth of Australia, 2010: Intergenerational Report Australia to 2050: Futures

Challenges. Commonwealth of Australia, Canberra.

Council of Capital City Lord Mayors, 2009: Towards a City Strategy: National Urban

Policy Submissions. Available at www.lordmayors.org. Downloaded Nov 292010.

Davidson, A., Stuck in a cul-de-sac? Suburban history and urban sustainability in Australia, Urban Policy and Research 24, 201-216.

Davis, M., 2010: Who will build the ark, New Left Review 61, 29-46.

Department of Immigration, 2009, Fact Sheet 2 - Key Facts in Immigration. Canberra.

Department of Planning, 2008: New South Wales State and Regional Population

Projections, 2006-2036: 2008 Release. Department of Planning, Sydney.

Dodson, J. and Sipe, N., 2008: Shocking the suburbs: Urban location, home ownership and oil vulnerability in the Australian city, Housing Studies 23, 377-401.

Essex, S. and Brown, G., 1997: The emergence of post-suburban landscapes on the North Coast of New South Wales: a case study of contested space. International Journal of Urban and Regional Research 21, 259-285.

Fagan, B. and Dowling, R., 2005: Neoliberalism and suburban employment: Western Sydney in the 1990s. Geographical Research 43, 71-81.

Foran, B. and Poldy, F., 2003: Between a rock and a hard place: Australia's population options to 2050 and beyond, People and Place 11, 1-15. 
Forrest, J., and Dunn, K., 2007: Constructing racism in Sydney: Australia's largest ethnicity, Urban Studies 44, 699-721.

Forster, C., 2006: The challenge of change: Australian cities and urban planning in the new millennium. Geographical Research 44, 173-82.

George, M., Smith, S., Swanson, D. and Tyman, J., 2004: Population projections. In Siegel, J. and Swanson, D. (eds) The Methods and Materials of Demography. Second Edition, Elsevier Academic Press, Amsterdam, 561-601.

Gleeson, B., Dodson, J. and Spiller, M., 2010: Metropolitan Governance for the Australian City: The Case for Reform, Issues Paper 12,Urban Research Program, Griffith University.

Gurran, N., 2008: Affordable housing: a dilemma for metropolitan planning, Urban Policy and Research 26, 101-110.

Holmes, J.H., 1987: Population. In Jeans, D. (ed.) Space and Society. Sydney University Press, Sydney, 24-48.

Holmes, J., 2006: Impulses towards a multifunctional transition in rural Australia: Gaps in the research agenda, Journal of Rural Studies 22, 142-160.

Houston, P., 2005: Re-valuing the frings: some findings on the value of agricultural production in Australia's peri-urban regions. Geographical Research 43, 209-223. Hugo, G., 2005: The state of rural populations. In Cocklin, C. and Dibden, J. (eds) Sustainability and Change in Rural Australia. University of New South Wales Press, Sydney, 56-79. 
Hugo, G., 2008a: Future urban population and settlement transitions. In P. Newton (ed.) Transitions: Pathways toward Sustainable Urban Development in Australia. CSIRO Publishing, Canberra, 149-70.

Hugo, G., 2008b: Immigrant settlement outside of Australia's capital cities, Population, space and place $14,553-571$.

Irvine, J. and Saulwick, J. 2009: Population growth head and shoulders above India. Sydney Morning Herald (23 September), 1.

James, C., 2009: Australian homes are the biggest in the world, ComSec Economic Insights November 30, Commonwealth Bank of Australia, Sydney.

Kaspura, A., 2006: Water and Australian Cities: Review of Urban Water Reform. Institution of Engineers, Australia. Available at www.engineersaustralia.org.au. Downloaded 25 Nov 2010.

Kelly, J.F., 2010: The Cities We Need. Grattan Institute Report No. 2010-4, Available at http://www.grattan.edu.au/programs/energy.php . Downloaded, Nov 15, 2010. McDonald, P., 2008: Demographic transitions. In P. Newton (ed.) Transitions: Pathways toward Sustainable Urban Development in Australia. CSIRO Publishing, Canberra, 133147.

Major Cities Unit, 2010: State of Australian Cities 2010. Infrastructure Australia, Australian Government, Canberra.

Moriarity, P., 2002, Environmental sustainability of large Australian cities, Urban Policy and Research 20, 233-44. 
Narushima, Y. 2010: Population big enough, majority of people say. Sydney Morning Herald (online), Oct 10, 2010.

National Housing Supply Council, 2010: 2010 State of Supply Report. Commonwealth of Australia, Canberra.

Neutze, M., 1978: Australian Urban Policy. George Allen and Unwin, London.

Newton, P. and Bai, X., 2008: Transitioning to sustainable urban development. In P. Newton (ed.) Transitions: Pathways toward Sustainable Urban Development in Australia. CSIRO Publishing, Canberra, 3-19.

Newton, P., (ed.), 2008a: Transitions: Pathways toward Sustainable Urban Development in Australia. CSIRO Publishing, Canberra.

Newton, P., 2008b: Metropolitan evolution. In P. Newton (ed.) Transitions: Pathways toward Sustainable Urban Development in Australia. CSIRO Publishing, Canberra, 171187.

O'Neill, P.M. 2010: Infrastructure financing and operation in the contemporary city. Geographical Research 48, 3-12.

O'Sullivan, M., and Wen, P. 2011: Australia stuck on a road to nowhere, Sydney Morning Herald (online), March 5, 2011.Queensland Government. 2008: Queensland Government Population Projections to 2056: Queensland and statistical divisions, Third edition, Brisbane.

Self, P., 1995: Alternative urban policies: the case for regional development. In P. Troy (ed.) Australian Cities - Issues, Strategies and Policies for Urban Australia in the 1990s. Cambridge University Press, Melbourne, pp. 246-257. 
Senate Select Committee on Housing Affordability in Australia, 2008: A Good House I

Hard to Find: Housing Affordability in Australia. Commonwealth of Australia, Canberra.

Smailes, P., T. Griffin and Argent, N. 2005: The changing social framework. In Cocklin,

C. and Dibden, J. (Eds.), Sustainability and Change in Rural Australia. UNSW Press,

Sydney, 80-102.

South Australian Department of Planning and Local Government, 2010:

http://www.planning.sa.gov.au/index

Spiller, M., 2010: Population: The Big Issue - The National Interest. ABC Radio,

Broadcast 21 May 2010.

Tanner, L., 2010: The Building Decade: the Infrastructure Challenge Facing Australia,

Address to the Austrlian Financial Review National Infrastructure Conference, 28 April.

Available at: www.financeminister.gov.au/archive/speeches/2010/sp 20100428.html.

Downloaded 6.3.11

Tonts, M. and Atherley, K., 2005: Rural restructuring and the changing geography of competitive sport. Australian Geographer 36, 125-144.

Tonts, M. and Haslam-McKenzie, F., 2005: Neoliberalism and changing regional policy in Australia. International Planning Studies 10, 183-200.

Tonts, M., 2005: Internal migration and Australia's agricultural regions. Dialogue 24, 53-65.

Tovey, J., 2010: Essential city workers who cannot afford to live in it, Sydney Morning Herald (online), October 16, 2010. 
Troy, P. 2001: The Management of Water in Australian Cities. Submission to Senate Commission Inquiry. Available at http://www.enviro-friendly.com/senate-submissiontroy.pdf. Downloaded 29th Nov 2010.

Water Services Association of Australia, 2010: Implications of Population Growth in Australia on Urban Water Resources. WSSA Occasional Paper No. 25. Available from https://www.wsaa.asn.au/About/News/Pages/OccasionalPaper25.aspx. Downloaded November 242010.

Wise, A., 2010: Sensuous multiculturalism: emotional landscapes of inter-ethnic living in suburban Australia. Journal of Ethic and Migration Studies 36, 917-937. 


\section{FIGURE CAPTIONS}

Figure 1. Distribution of population by settlement size, Australia, 1966, 1996, 2001, 2006 (\%)

Figure 2: Estimated resident population, major cities, 2009

Figure 3: Projected population growth, capital cities, 2010-2056

Figure 4: Projected age structure of metropolitan and non-metropolitan regions, New South Wales, Queensland and Victoria, 2010 and 2050

Figure 5: Environmental/locational zones of rural south-eastern Australia

Figure 6: Rural population density (occupied dwellings per 100 sq. km), 2001 
Table 1 Distribution of the Australian population by settlement category, 1996-2006

\begin{tabular}{l|r|r|r}
\hline & \multicolumn{2}{c}{1996} & \multicolumn{2}{c}{2001} & \multicolumn{1}{c}{2006} \\
\hline & (nos.- '000s) & \multicolumn{1}{c}{ (nos.- '000s) } & (nos.- '000s) \\
\hline 00000 and over & 9512 & 10349 & 10986 \\
100000 - 499 999 & 1658 & 1996 & 2110 \\
$20000-99999$ & 1637 & 1772 & 1896 \\
$2000-19999$ & 1837 & 2000 & 2054 \\
$1000-1999$ & 409 & 410 & 417 \\
\hline
\end{tabular}

Source: Australian Bureau of Statistics, various years

Table 2 Social costs of urban congestion, capital cities, 2005-2025

\begin{tabular}{|l|l|l|l|l|l|}
\hline Capital city & 2005 & 2025 & Capital city & 2005 & 2025 \\
\hline Sydney & $3.5(\$ \mathrm{~b})$ & $7.8(\$ \mathrm{~b})$ & Adelaide & $0.6(\$ \mathrm{~b})$ & $1.1(\$ \mathrm{~b})$ \\
\hline Melbourne & $3.0(\$ \mathrm{~b})$ & $6.1(\$ \mathrm{~b})$ & Canberra & $0.11(\$ \mathrm{~b})$ & $0.2(\$ \mathrm{~b})$ \\
\hline Brisbane & $1.2(\$ \mathrm{~b})$ & $3.0(\$ \mathrm{~b})$ & Hobart & $50(\$ \mathrm{~m})$ & $70(\$ \mathrm{~m})$ \\
\hline Perth & $0.9(\$ \mathrm{~b})$ & $2.1(\$ \mathrm{~b})$ & Darwin & $18(\$ \mathrm{~m})$ & $35(\$ \mathrm{~m})$ \\
\hline
\end{tabular}

Source: BITRE (2007) 
Table 3 Current state capital city metropolitan strategies population growth and additional dwelling estimates

\begin{tabular}{|l|l|l|}
\hline Metropolitan strategy (date) & $\begin{array}{l}\text { Population } \\
\text { growth }\end{array}$ & Additional dwelling demand \\
\hline Metropolitan: Sydney 2036 (2010) & 1700000 & 770000 \\
\hline Melbourne 2030 (2005) & 950000 & 620000 \\
\hline $\begin{array}{l}\text { South-East Queensland Regional } \\
\text { Plan 2009-2031 (2009) }\end{array}$ & 1400000 & 754000 \\
\hline Perth Directions 2031 (2010) & 500000 & 328000 \\
\hline $\begin{array}{l}\text { The 30 Year Plan for Greater } \\
\text { Adelaide (2010) }\end{array}$ & 560000 & 258000 \\
\hline
\end{tabular}

Source: Capital city metropolitan strategies

Table Residential water consumption kL per capita annually, capital cities, 20092056

\begin{tabular}{|l|l|l|l|}
\hline & Actual 2009 & Projected 2026 & Projected 2056 \\
\hline Sydney & 74 & 70 & 63 \\
\hline Melbourne & 57 & 63 & 59 \\
\hline $\begin{array}{l}\text { SEQ (including } \\
\text { Brisbane) }\end{array}$ & 53 & 84 & 84 \\
\hline Adelaide & 83 & 85 & 76 \\
\hline Perth & 106 & 87 & 78 \\
\hline
\end{tabular}

Source: WSSA (2010) 
Table 5 Change in total community population, town size, urban concentration and rural density, by major zone, south-eastern Australia, 1981-2001

\begin{tabular}{|c|c|c|c|c|c|c|c|c|c|}
\hline Zone & & $\begin{array}{l}\text { Popn. of } \\
\text { community } \\
\text { main town }\end{array}$ & & & $\begin{array}{l}\text { Proportion } \\
\text { living in } \\
\text { towns }\end{array}$ & & & $\begin{array}{l}\text { Rural } \\
\text { popn. } \\
\text { density* }\end{array}$ & \\
\hline & Median & Median & $\begin{array}{c}\% \\
\text { change }\end{array}$ & Median & Median & $\begin{array}{l}\% \\
\text { point } \\
\text { change }\end{array}$ & Median & Median & $\begin{array}{l}\% \\
\text { change }\end{array}$ \\
\hline & 1981 & 2001 & $\begin{array}{l}\text { 1981- } \\
2001\end{array}$ & 1981 & 2001 & $\begin{array}{l}\text { 1981- } \\
2001\end{array}$ & 1981 & 2001 & $\begin{array}{l}\text { 1981- } \\
2001\end{array}$ \\
\hline Tablelands/ranges & 1614 & 1661 & 2.9 & 58.3 & 59.8 & 1.5 & 25 & 31 & 24.0 \\
\hline High access & 2667 & 3454 & 29.5 & 64.2 & 68.4 & 4.2 & 97 & 169 & 74.2 \\
\hline Mixed farm & 2044 & 2842 & 39.0 & 65.7 & 67.6 & 1.9 & 58 & 78 & 34.5 \\
\hline Coastal & 2172 & 3040 & 40.0 & 66.6 & 74.8 & 8.2 & 161 & 231 & 43.5 \\
\hline Inland/remote & 951 & 953 & 0.2 & 54.3 & 58.3 & 4.0 & 14 & 13 & -7.1 \\
\hline
\end{tabular}

*Number of occupied dwellings per $100 \mathrm{~km}^{2}$

Source: Smailes, et al., 2005, p. 89. 
i However, it is also a well-accepted point that projecting internal migration trends can be an exercise fraught with uncertainty. Central to the cohort-component method of projection is the application of survival, fertility and migration rates to each cohort of a target population. Therefore, the resulting projections reflect both the structure of the population and past rates of change. At a regional scale, migration is frequently the greatest determinant of population change but is also the demographic process that is most responsive to local economic and environmental change. This makes it the most difficult vital rate to model accurately (George, et al., 2004).

ii Not all metropolitan strategies include employment projections. However these projections generally track closely with the anticipated need for new dwellings, suggesting that Melbourne will need in the order of 620000 additional jobs and the South-East Queensland region an additional 754000.

iii Particularly older industrial middle and outer suburbs (e.g. Sydney's central and western sub-regions, Melbourne's central-west and northern suburbs, Adelaide's northern regions), and traditionally industrial regional cities (e.g. Newcastle, Wollongong, Geelong) (O'Neill, 2010).

iv Among the major cities, for example, Sydney (53.3 per cent) and Melbourne (56.2 per cent) have the highest proportion of 15-24 year olds in any form of education, compared the Sunshine Coast (43.5 per cent ), Gold Coast-Tweed (42.5 per cent) and Darwin ( 35 per cent), which have the lowest proportion. Similarly for 25-34 year olds who have completed year 12 , Sydney (75.9 per cent) and Melbourne (76.6 per cent) compared with Wollongong (59.9 per cent) and Newcastle (55.7 per cent) at the other end of the spectrum (McDonald, 2008).

v Rental affordability has equally declined, especially in the capital cities. For instance, central Sydney rentals on a 2-bed unit, at $\$ 600$ per week, would demand 75 per cent of the average income of a childcare worker; 74 per cent for a hospitality worker; or 41 per cent for a police/firefighter (Tovey, 2010).

vi As Gurran (2008) points out, even where state government plans include affordable housing commitments, local governments are still the locus of implementation and here both capacity and political commitment varies.

vii One indication of the effect of homeownership on wealth accumulation potential is the fact that 92 per cent of households in the lowest net worth quintile are renters (ABS 2007).

viii New houses in Australia are now the world's largest, averaging 83sq m per person, a 245 per cent increase on 1985-6 (James, 2009). The average house size in Melbourne has increased from 176 square metres in 1991 to 253 square metres in 2003, while average household size has fallen to 2.61 people in 2001 (DSE, 2006 cited in Buxton and Scheurer, 2007).

ix For example, Sydney's Northwestern and Southwestern sectors to be released for development contain 52 per cent of the region's vegetable farming properties, 60 per cent of greenhouse industries and 46 per cent of hydroponic vegetable industries (Major Cities Unit, 2010).

$\mathrm{x}$ Major shifts in housing and urban design, socio-demographic shifts such as more, smaller households, uptake of water efficiency applications, water pricing and water use regulation might alter these predictions.

xi A system whereby surface water is captured outside the city, filtered, used once, treated and discharged, such that the rain that falls on cities is not captured but positioned as problematic stormwater to be disposed of quickly (Kaspura, 2006). 
xii The greater potential for recycled water use lies in the inland cities and towns. The major cities' predominantly coastal location militates against recycling which normally locates at the lowest point in the catchment. Pumping uphill for later use is prohibitively expensive.

xiii Roughly 1 in 3 residents in Sydney, Melbourne and Perth were born overseas, 1 in 5 for Brisbane and Adelaide along with a group of second tier cities such as Geelong, Gold Coast, Wollongong, Darwin, and around 1 in 10 in Hobart and Newcastle (McDonald, 2008).

xiv Notably in the 2005 Cronulla riots in Sydney, and a string of violent attacks against Indian residents in Melbourne in 2009.

xv The 18 major cities are currently governed by 157 local governments, eight states or territories and Federal government (Major Cities Unit, 2010).

xvi This includes criteria around population, economic growth, climate change, housing affordability and congestion 